\title{
RANCANG BANGUN APLIKASI PELAPORAN DANA ALOKASI KHUSUS BERBASIS WEB (Studi Kasus: BAPPEDA Provinsi Sulawesi Utara)
}

\author{
Rivani Kumase ${ }^{1}$, Gerald Rawis ${ }^{2}$, Junaidy B. Sanger ${ }^{3}$ \\ Program Studi Teknik Informatika ${ }^{123}$ \\ Universitas Katolik De La Salle Manado ${ }^{123}$ \\ e-mail: 12013012@unikadelasalle.ac.id ${ }^{1}$, grawis@unikadelasalle.ac.id ${ }^{2}$, \\ jsanger@unikadelasalle.ac.id ${ }^{3}$
}

\begin{abstract}
This study aims to establish a special allocation reporting application based on web. The method used to build the system is Rapid Application Development (RAD), which consists of requirements analysis, modeling analysis, modeling and design of construction. Application development using PHP, in this case CodeIgniter and MySQL. The results showed that the application is built easy to use, all the functions that run as expected, and the user needs can be met.
\end{abstract}

Keywords: $\quad$ Web Application, RAD, PHP, CodeIgniter, MySQL

\section{A. PENDAHULUAN}

Badan Perencanaan Pembangunan Daerah (BAPPEDA) merupakan Perangkat Daerah Provinsi yang membantu Kepala Daerah dalam menyelenggarakan Pemerintahan Daerah. BAPPEDA Provinsi Sulawesi Utara (Sulut) memiliki beberapa bidang yang mendukung proses kerja dan Bidang Pengendalian dan Pelaporan merupakan salah satu bidang yang berada didalamnya yang bertugas melakukan penyelenggaraan di Bidang Monitoring, Pelaporan, Analisa dan Evaluasi. Bidang Pengendalian dan Pelaporan membawahi dua Sub Bidang yakni Sub Bidang Analisa dan Evaluasi serta Sub Bidang Monitoring dan Pelaporan.

Sub Bidang Monitoring dan Pelaporan bertugas dan bertanggungjawab untuk mengumpulkan Laporan Dana Alokasi Khusus (DAK) dari Satuan Kerja Perangkat Daerah (SKPD) Provinsi dan Kabupaten/Kota setiap triwulan. SKPD Provinsi dan BAPPEDA Kabupaten/Kota yang telah menyelesaikan laporan DAK membawa laporan tersebut ke Sub Bidang Monitoring dan Pelaporan BAPPEDA Provinsi. Setelah laporan DAK terkumpul dilakukan identifikasi laporan dan kemudian diadakan rapat internal.

Proses pengumpulan laporan DAK tersebut menimbulkan beberapa masalah seperti, pemeriksaan laporan DAK masih banyak yang tertunda karena keterlambatan pengumpulan laporan dari BAPPEDA Kabupaten/Kota. Hal ini disebabkan belum lengkapnya laporan yang dari SKPD dari masing-masing Kabupaten/Kota dan jauhnya jarak tempuh untuk mengumpulkan laporan secara langsung. Masalah lainnya yakni lemahnya tingkat keakurasian perhitungan setiap total pada laporan DAK yang dilakukan oleh BAPPEDA Kabupaten/Kota sehingga menyebabkan pihak Sub Bidang Monitoring dan Pelaporan melakukan pekerjaan dua kali. Penyebab masalah di atas yakni penggunaan rumus yang salah dan kesalahan dalam pengisian data. Menggunakan format tabel yang tidak sesuai standar sehingga 
menyebabkan kesulitan dalam pemeriksaan laporan DAK. Masalah ini disebabkan tidak dibagikannya template tabel standar untuk membuat laporan DAK.

Berdasarkan uraian masalah yang ada, maka dapat dilihat bahwa Sub Bidang Monitoring dan Pelaporan membutuhkan sebuah aplikasi yang dapat mempermudah dalam penerimaan laporan DAK dari BAPPEDA Kabupaten/Kota. Alasan menggunakan web dikarenakan untuk mempermudah SKPD untuk membuat laporan dan mempermudah dalam pemasukkan laporan DAK bagi yang jaraknya jauh sehingga lebih efektif karena dapat dilakukan dimana saja.

Tujuan dari penelitian ini adalah untuk membangun Aplikasi Pelaporan Dana Alokasi Khusus Berbasis Web yang dapat membantu Sub Bidang Monitoring dan Pelaporan dalam penerimaan laporan DAK.

\section{B. TINJAUAN PUSTAKA}

\section{Dana Alokasi Khusus}

Dana Alokasi Khusus (DAK) merupakan dana dari pemerintah pusat yang diberikan atau disalurkan kepada pemerintah provinsi dan pemerintah provinsi menyalurkannya ke pemerintah kabupaten/kota untuk menunjang program kegiatan yang dilaksanakan oleh pemerintah provinsi dan kabupaten/kota. Keputusan Menteri Keuangan No. 556/KMK.03/2000 tentang Tata Cara Penyaluran Dana Alokasi Umum dan Dana Alokasi Khusus yang dikutip dari DAK (2015) menuliskan bahwa Dana Alokasi Khusus yang selanjutnya disebut DAK adalah dana yang dapat dialokasikan dari APBN kepada Daerah tertentu untuk membantu membiayai kebutuhan khusus, dengan memperhatikan tersedianya dana dalam APBN. Sedangkan menurut UndangUndang No. 33 Tahun 2004 tentang Perimbangan Keuangan antara Pemerintah Pusat dan Pemerintah Daerah menyatakan bahwa Dana Alokasi Khusus (DAK) adalah dana yang bersumber dari pendapatan APBN yang dialokasikan kepada daerah tertentu dengan tujuan untuk membantu mendanai kegiatan khusus yang merupakan urusan daerah dan sesuai dengan prioritas nasional.

\section{Aplikasi Web}

Menurut Raharjo et al. (2014), aplikasi web adalah aplikasi yang tersimpan dan dieksekusi pada web server. Permintaan dilakukan oleh pengguna aplikasi web melalui web browser dan hasilnya akan ditampilkan kembali oleh aplikasi di web browser.

Simarmata (2010) mendefinisikan aplikasi web sebagai sistem informasi yang merupakan bagian client-side yang dijalankan browser web. Dalam membangun aplikasi web digunakan 3-tier (n-tier) sebagai arsitekturnya karena arsitektur 3-tier terdiri dari client (antarmuka), server (pemrosesan), dan database (validasi).

\section{PHP}

Menurut Nugroho (2008), PHP adalah bahasa standar yang hanya dapat dijalankan pada sisi server dan hasil eksekusi dari interpreter ditampilkan pada sisi client. PHP membutuhkan interpreter untuk mengeksekusi kode PHP, tanpa interpreter kode dan aplikasi PHP tidak dapat dijalankan.

Raharjo et al. (2014) menjelaskan bahwa PHP merupakan bahasa pemrograman script yang berjalan di sisi server karena script $\mathrm{PHP}$ diproses pada web server. Script yang ditulis dengan PHP diterjemahkan oleh interpreter PHP untuk diterjemahkan ke dokumen HTML kemudian ditampilkan pada browser web.

\section{CodeIgniter}

CodeIgniter menurut Syuhada (2015) merupakan salah satu framework dalam 
pengembangan web. CodeIgniter merupakan framework yang menerapkan sistem MVC (Model-View-Controller) dalam penggunaannya sehingga pengkodean yang rumit dengan PHP menjadi lebih sederhana dengan penerapan MVC.

Menurut Hidayatullah dan Kawistara (2015), CodeIgniter adalah salah satu framework PHP yang terdapat fitur yang lengkap aplikasi web. CodeIgniter menggunakan metode MVC (Model View Controller) dimana metode ini memisahkan antara data logic (Model) dari presentation logic (View) dan process logic (Controller) sehingga dengan menggunakan framework lebih menghemat waktu pengembangan.

\section{Basis Data}

Menurut Puspitosari (2011), basis data adalah kumpulan informasi atau data yang disimpan dalam komputer dan sumber informasi yang diperiksa menggunakan suatu program. DBMS (Database Management System) diperlukan untuk mengelola, mengontrol, membuat, dan mengakses basis data dengan mudah. Basis data terdiri dari tabel yang terdapat kolom (field) dan baris (record). Dalam membuat basis data harus diperhatikan bahwa setiap tabel harus memiliki kolom yang unik sebagai Primary Key, tidak boleh adanya pengulangan data dan harus memilih tipe data yang tepat.

Raharjo (2011) mendefinisikan basis data sebagai kumpulan data yang saling terintegrasi dan dapat diatur sedemikian rupa sehingga kumpulan data tersebut dapat diubah, diambil dan dicari dengan cepat. Basis data terdiri dari beberapa model dimana salah satunya adalah model relasional. Basis data juga didefinisikan sebagai kumpulan tabel karena data yang berada dalam basis data diklasifikasikan berdasarkan jenis dan disimpan pada tabel yang terdiri dari kolom dan baris.
MySQL

Nugroho (2008) menuliskan bahwa MySQL (My Structured Query Language) adalah program yang membuat dan mengelola basis data yang disebut DBMS (DataBase Management System). DBMS bersifat Open Source sehingga dapat digunakan oleh siapa saja. Kelebihan MySQL yakni dapat diakses oleh banyak pengguna karena bersifat jaringan dan menggunakan bahasa query yang merupakan bahasa standar SQL (Structured Query Language). Hampir semua aplikasi mendukung MySQL baik aplikasi Open Source atau tidak, karena MySQL tidak akan berjalan tanpa aplikasi yang dapat mengakses basis data.

MySQL menurut Raharjo (2011) merupakan aplikasi RDBMS (Relational Database Management System) atau server database yang mengelola data dengan sangat cepat, menyimpan data dalam jumlah yang sangat besar, dapat diakses oleh banyak pengguna, dapat melakukan proses secara bersamaan. Kelebihan MySQL yakni dapat digunakan untuk aplikasi berbasis desktop dan web, memiliki kemampuan mengolah data yang cepat, dapat digunakan pada berbagai sistem operasi, dapat digunakan secara gratis dibawah GNU General Public License dan dapat menggunakan MySQL yang bersifat komersial dengan kemampuan lebih spesifik dari yang gratis.

\section{METODE}

Metode yang digunakan untuk membangun Aplikasi Pelaporan Dana Alokasi Khusus Berbasis Web adalah Rapid Application Development (RAD). RAD menurut Rosa dan Shalahuddin (2015) adalah model proses pengembangan perangkat lunak yang bersifat inkremental terutama karena waktu pengerjaan yang cukup singkat. RAD merupakan adaptasi 
dari model air terjun (waterfall) tetapi dengan versi pengerjaan yang sangat cepat.

Metodologi ini terdiri dari empat fase utama yakni analisis persyaratan, analisis pemodelan, desain pemodelan, dan konstruksi.

\section{HASIL DAN PEMBAHASAN}

\section{Analisis Pemodelan}

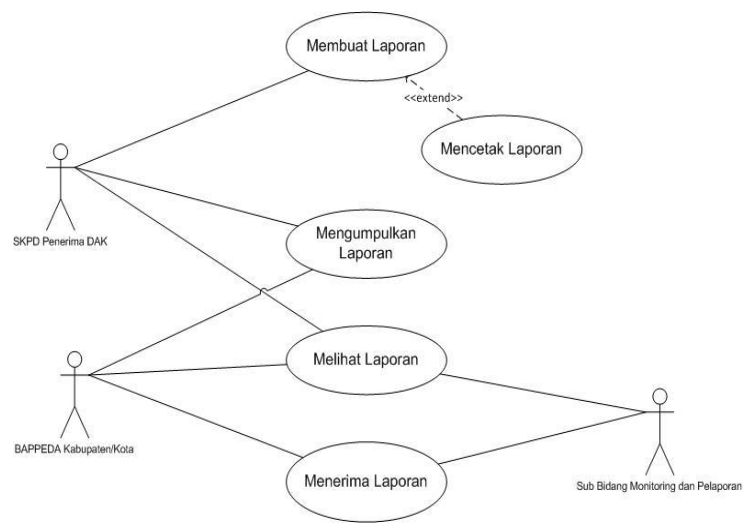

Gambar 1. Use Case Diagram Sistem yang sedang berjalan

Diagram pada Gambar 1 menjelaskan proses pelaporan DAK dari setiap SKPD penerima DAK yang membuat laporan DAK setiap triwulan sebagai laporan pertanggungjawaban untuk program kegiatan yang sedang dan/atau telah dilaksanakan, laporan yang telah selesai kemudian dikumpulkan ke BAPPEDA Kabupaten/Kota untuk SKPD Kabupaten/Kota dan ke BAPPEDA Provinsi (Sub Bidang Monitoring dan Pelaporan) untuk SKPD Provinsi. Diagram pada Gambar 2 menjelaskan mengenai SKPD penerima DAK membuat laporan DAK dan mengumpulkan laporan DAK yang telah selesai dibuat setiap triwulan. Setelah itu laporan DAK yang telah diterima akan dilakukan pemeriksaan kembali. Jika tidak lengkap atau ditemukan kesalahan maka dilakukan perhitungan kembali sebagai pencocokan data dan jika tidak ditemukan kesalahan maka semua laporan yang telah terkumpul akan digabungkan menjadi laporan akhir triwulan.

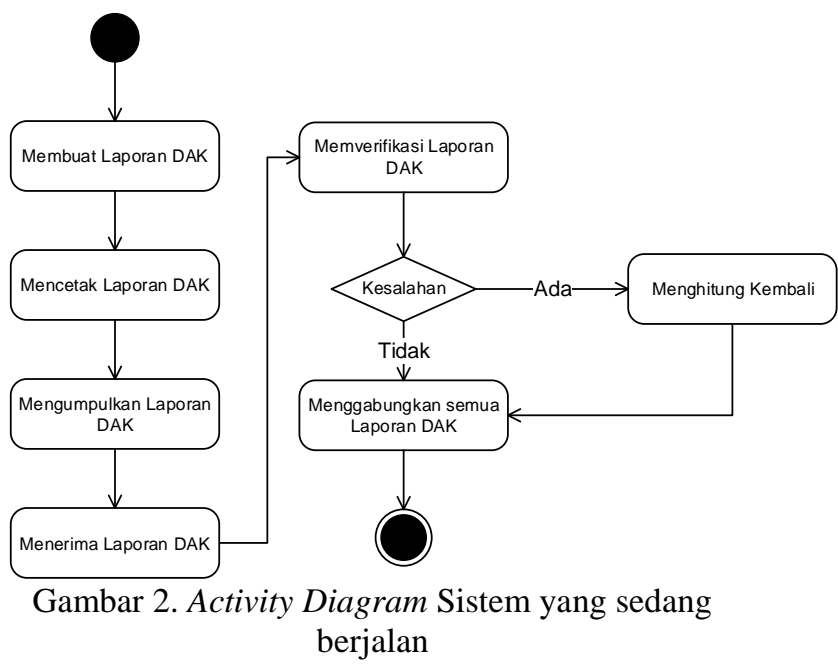

\section{Desain Pemodelan}

Fase desain pemodelan bertujuan untuk melakukan perancangan sistem berdasarkan analisis yang telah dilakukan sebelumnya. Hasil dari fase desain pemodelan adalah antarmuka dan spesifikasi desain.

Diagram pada Gambar 3 menjelaskan semua aktor wajib melakukan login untuk dapat masuk ke aplikasi. Staf membuat dan mengirim laporan DAK ke Sub Bidang Monitoring dan Pelaporan. Aktor yang terlibat dalam Aplikasi Pelaporan Dana Alokasi Khusus Berbasis Web ini terdiri dari admin dan staf BAPPEDA Kabupaten/Kota. Diagram pada Gambar 4 menjelaskan hubungan yang terjadi antara pengguna sistem dalam hal ini pembuatan laporan. Laporan_dak merupakan tabel yang akan menampung semua data yang akan diisi untuk menjadi sebuah laporan. Laporan_pagu menjadi bagian dari laporan_dak karena hasil dari laporan_pagu diambil dari laporan_dak.

Gambar 5 menjelaskan aktivitas yang dilakukan oleh admin mulai dari melakukan login dan aplikasi menampilkan fitur-fitur yang berhubungan dengan admin. Gambar 6 menjelaskan aktivitas yang dilakukan oleh 
staf mulai dari melakukan login dan aplikasi menampilkan fitur-fitur yang berhubungan dengan staf. Aktivitas utama yang dilakukan oleh staf yakni membuat laporan DAK sampai mengirimnya ke Admin.

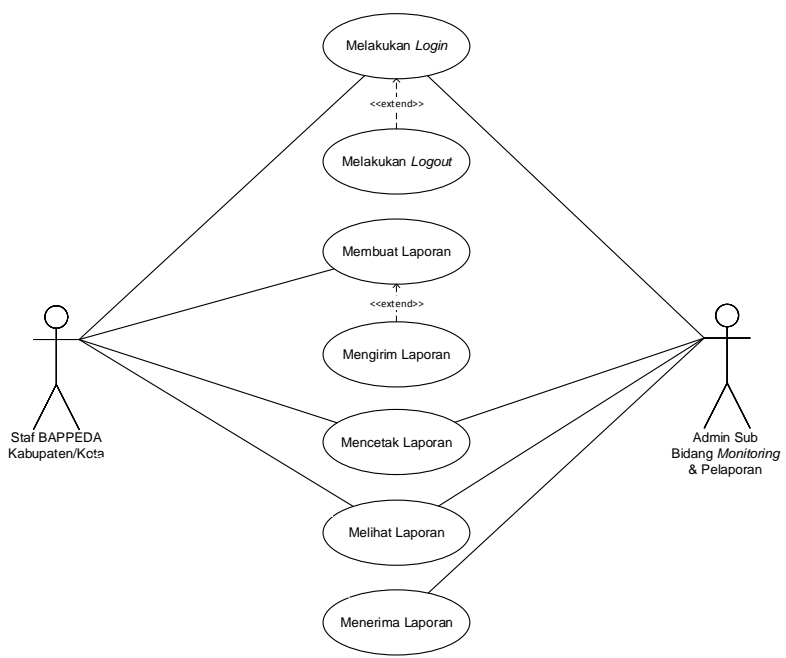

Gambar 3. Use Case Diagram Sistem baru

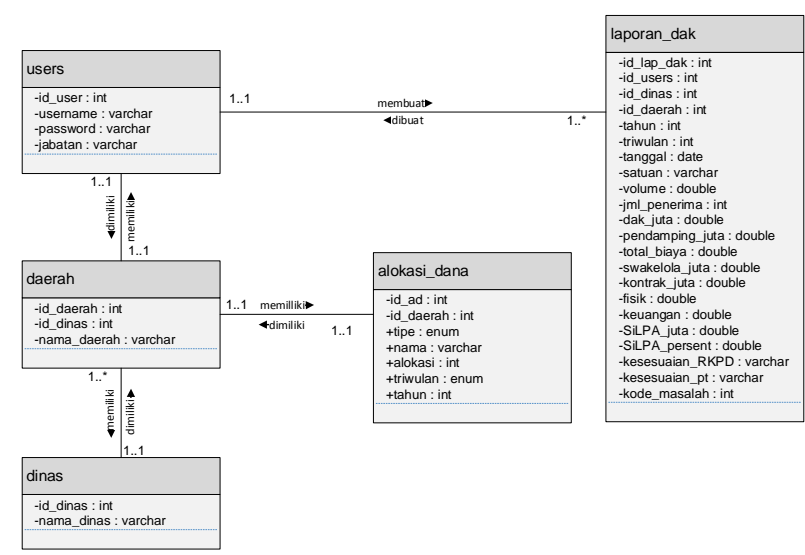

Gambar 4. Class Diagram Sistem baru

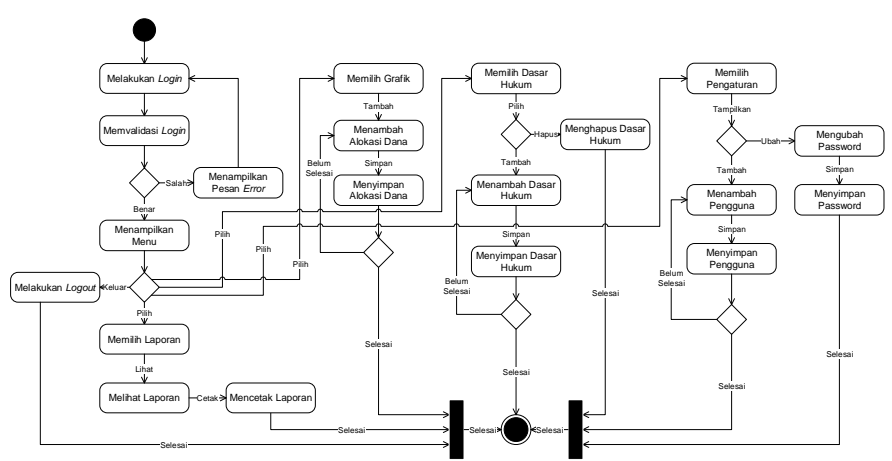

Gambar 5. Activity Diagram Sistem baru - Admin

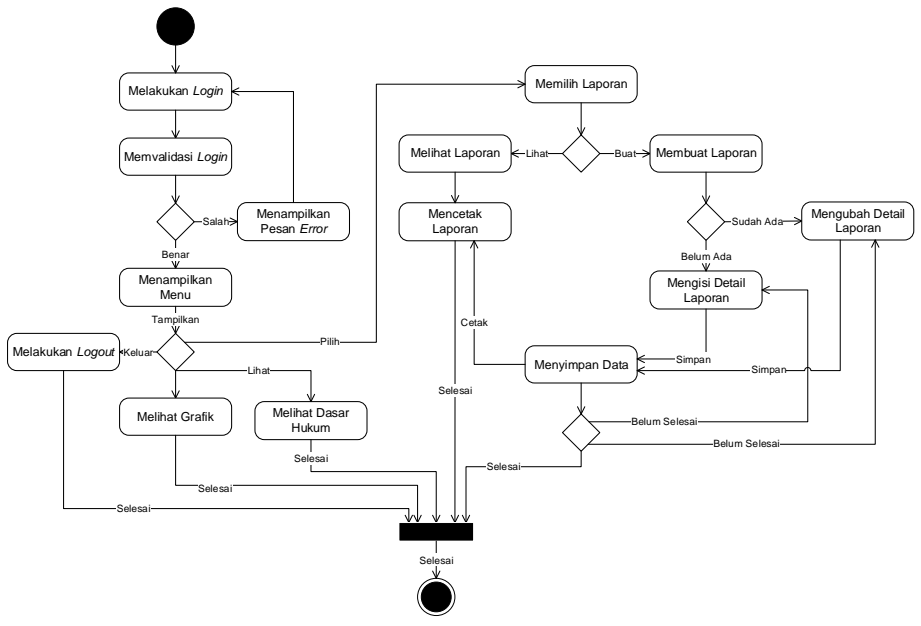

Gambar 6. Activity Diagram Sistem baru - Staf

\section{Konstruksi}

Spesifikasi Perangkat Keras dan Perangkat Lunak dalam pembangunan aplikasi ditunjukkan pada Tabel 1 dan Tabel 2.

Tabel 1. Spesifikasi Perangkat Keras

\begin{tabular}{|l|l|}
\hline \multicolumn{1}{|c|}{ Nama } & \multicolumn{1}{c|}{ Rekomendasi } \\
\hline Processor & Intel ${ }^{\mathrm{C}}$ Core $\mathrm{TM}$ i3-4010U $1.70 \mathrm{GHz}$ \\
\hline Memory & 2 GB \\
\hline Harddisk & 2 GB (free space) \\
\hline \multicolumn{1}{|c|}{ Nama } & \multicolumn{1}{|c|}{ Rekomendasi } \\
\hline Operating System & Windows 8 Pro 64-bit \\
\hline Lain-lain & Mouse, keyboard dan printer \\
\hline
\end{tabular}

Tabel 2. Spesifikasi Perangkat Lunak

\begin{tabular}{|l|l|}
\hline \multicolumn{1}{|c|}{ Nama } & \multicolumn{1}{c|}{ Fungsi } \\
\hline Apache v2.4.4 & Web server \\
\hline MySQL 5.5.32 & Pembuatan database \\
\hline phpMyAdmin 4.0.4 & Pengaturan database \\
\hline Microsift Word 2013 & Membuat laporan \\
\hline Microsoft Visio 2013 & $\begin{array}{l}\text { Membuat diagram dan } \\
\text { perancangan storyboard }\end{array}$ \\
\hline Sublime Text 3 & $\begin{array}{l}\text { Text editor untuk melakukan } \\
\text { pemrograman }\end{array}$ \\
\hline $\begin{array}{l}\text { Google Chrome versi } \\
\text { 48.0.2564.109 m (64-bit) }\end{array}$ & Menjalankan aplikasi \\
\hline
\end{tabular}

Aplikasi Pelaporan Dana Alokasi Khusus Berbasis Web menggunakan MySQL dalam membuat basis data. Tampilan tabel-tabel yang ada dalam basis data ditunjukkan pada Gambar 7, Gambar 8, Gambar 9, Gambar 10, dan Gambar 11.

\footnotetext{
\# Name Type Collation Attributes Null Default Extra

1 idk int(10) No None AUTO_INCREMENT

2 nama varchar(50) latin1_swedish_ci No None
}

Gambar 7. Implementasi Tabel Daerah 
Tabel daerah pada Gambar 7 berguna untuk menyimpan daftar daerah (kabupaten/kota) yang berada di Sulawesi Utara.

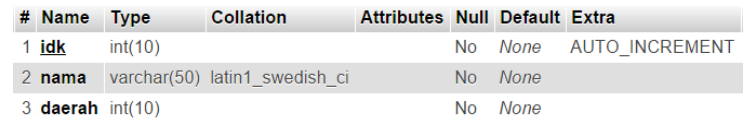
Gambar 8. Implementasi Tabel Dinas

Tabel dinas pada Gambar 8 berguna untuk menyimpan daftar dinas kabupaten/kota. Tabel laporan_dak pada Gambar 9 berguna untuk menyimpan data-data yang di-input saat membuat laporan. Tabel users pada Gambar 10 berguna untuk menyimpan daftar pengguna aplikasi. Tabel alokasi_dana pada Gambar 11 berguna untuk menunjukkan jumlah dana yang diperoleh setiap daerah.

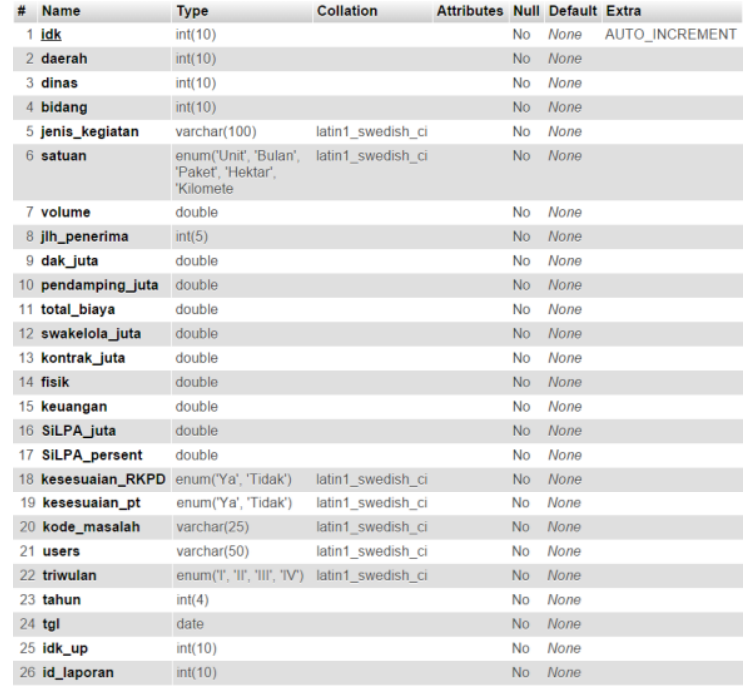

Gambar 9. Implementasi Tabel Laporan DAK

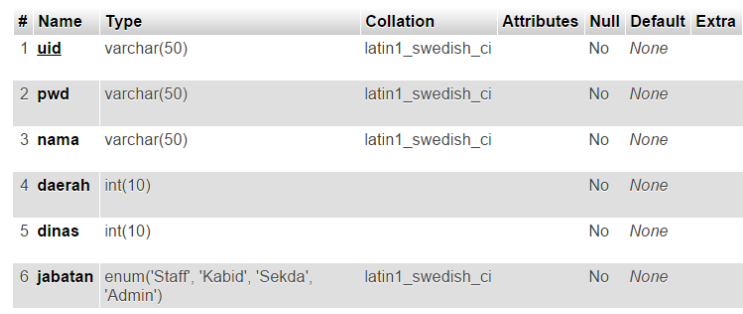

Gambar 10. Implementasi Tabel Users

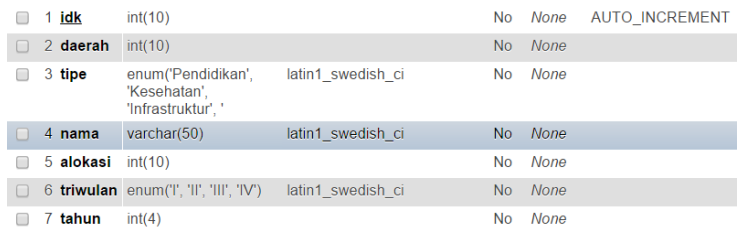

Gambar 11. Implementasi Tabel Alokasi Dana

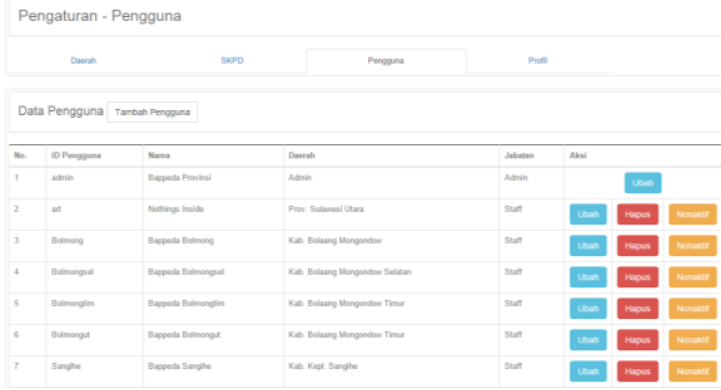

Gambar 12. Tampilan Halaman Pengaturan Pengguna

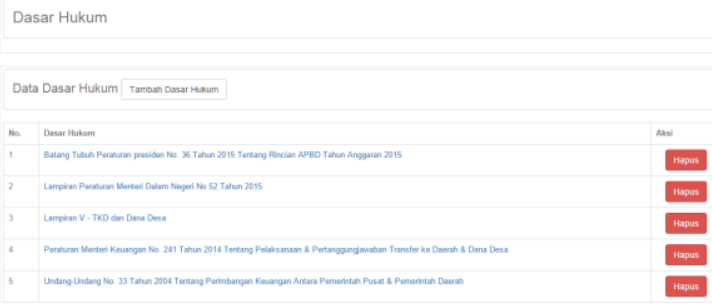

Gambar 13. Tampilan Halaman Dasar Hukum

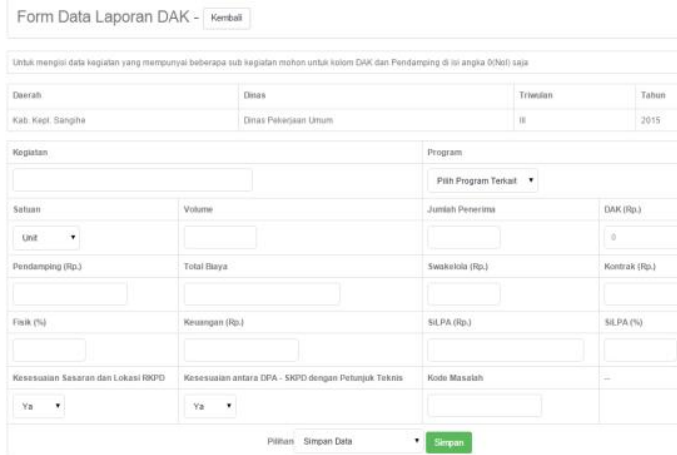

Gambar 14. Tampilan Membuat Laporan DAK

Kriteria pengujian dalam pembangunan aplikasi ini terdiri dari beberapa kriteria yakni:

1. Aplikasi yang dibangun mudah digunakan

2. Semua fungsi yang ada berjalan sesuai yang diharapkan

3. Kebutuhan pengguna dapat terpenuhi 
Adapun kasus pengujian sebagai berikut:

1. Username dan password yang dimasukkan dapat dibaca oleh aplikasi

2. Setiap perubahan yang dilakukan tersimpan dalam database

3. Menampilkan grafik berdasarkan data yang ada

4. Mencetak laporan berdasarkan triwulan dan tahun yang dipilih

5. Mengunggah dan mengunduh dokumen

Pelaksanaan pengujian pada Tabel 3 dilakukan untuk mengetahui hasil yang terjadi sesuai dengan yang diharapkan.

Tabel 3. Pelaksanaan Pengujian

\begin{tabular}{|c|c|c|c|}
\hline No. & Proses & Ekspektasi & Hasil Sebenarnya \\
\hline \multicolumn{4}{|c|}{ Form login } \\
\hline 1. & $\begin{array}{l}\text { Benar } \\
\text { memasukkan } \\
\text { username dan } \\
\text { password } \\
\end{array}$ & Masuk ke aplikasi & Masuk ke aplikasi \\
\hline 2. & $\begin{array}{l}\text { Salah } \\
\text { memasukkan } \\
\text { username dan } \\
\text { password }\end{array}$ & $\begin{array}{l}\text { Aplikasi } \\
\text { menampilkan pesan } \\
\text { error }\end{array}$ & $\begin{array}{l}\text { Aplikasi } \\
\text { menampilkan pesan } \\
\text { error }\end{array}$ \\
\hline \multicolumn{4}{|c|}{ Admin } \\
\hline 1. & $\begin{array}{l}\text { Memilih menu } \\
\text { grafik }\end{array}$ & $\begin{array}{l}\text { Menampilkan form } \\
\text { grafik }\end{array}$ & $\begin{array}{l}\text { Menampilkan form } \\
\text { grafik }\end{array}$ \\
\hline 2. & $\begin{array}{l}\text { Memilih } \\
\text { tambah data } \\
\text { grafik }\end{array}$ & $\begin{array}{l}\text { Menampilkan form } \\
\text { untuk tambah data } \\
\text { grafik }\end{array}$ & $\begin{array}{l}\text { Menampilkan form } \\
\text { untuk tambah data } \\
\text { grafik }\end{array}$ \\
\hline 3. & $\begin{array}{l}\text { Mengisi data } \\
\text { grafik }\end{array}$ & $\begin{array}{l}\text { Aplikasi menambah } \\
\text { dan menyimpan } \\
\text { data yang baru ke } \\
\text { database }\end{array}$ & $\begin{array}{l}\text { Aplikasi menambah } \\
\text { dan menyimpan } \\
\text { data yang baru ke } \\
\text { database }\end{array}$ \\
\hline 4. & $\begin{array}{l}\text { Mengubah } \\
\text { data grafik }\end{array}$ & $\begin{array}{l}\text { Aplikasi mengubah } \\
\text { data lama dan } \\
\text { menyimpan data } \\
\text { yang baru pada } \\
\text { database }\end{array}$ & $\begin{array}{l}\text { Aplikasi mengubah } \\
\text { data lama dan } \\
\text { menyimpan data } \\
\text { yang baru pada } \\
\text { database }\end{array}$ \\
\hline 5. & $\begin{array}{l}\text { Memilih } \\
\text { tampilkan data } \\
\text { grafik }\end{array}$ & $\begin{array}{l}\text { Aplikasi } \\
\text { menampilkan } \\
\text { grafik }\end{array}$ & $\begin{array}{l}\text { Aplikasi } \\
\text { menampilkan } \\
\text { grafik }\end{array}$ \\
\hline 6. & $\begin{array}{l}\text { Memilih menu } \\
\text { laporan }\end{array}$ & $\begin{array}{l}\text { Menampilkan form } \\
\text { laporan }\end{array}$ & $\begin{array}{l}\text { Menampilkan form } \\
\text { laporan }\end{array}$ \\
\hline 7. & $\begin{array}{l}\text { Melihat } \\
\text { laporan }\end{array}$ & $\begin{array}{l}\text { Aplikasi } \\
\text { menampilkan daftar } \\
\text { laporan }\end{array}$ & $\begin{array}{l}\text { Aplikasi } \\
\text { menampilkan daftar } \\
\text { laporan }\end{array}$ \\
\hline 8. & $\begin{array}{l}\text { Mencetak } \\
\text { laporan }\end{array}$ & $\begin{array}{l}\text { Aplikasi } \\
\text { menampilkan form } \\
\text { cetak dan mencetak } \\
\text { laporan }\end{array}$ & $\begin{array}{l}\text { Aplikasi } \\
\text { menampilkan form } \\
\text { cetak dan mencetak } \\
\text { laporan }\end{array}$ \\
\hline 9. & $\begin{array}{l}\text { Memilih menu } \\
\text { pengaturan }\end{array}$ & $\begin{array}{l}\text { Menampilkan form } \\
\text { pengaturan }\end{array}$ & $\begin{array}{l}\text { Menampilkan form } \\
\text { pengaturan }\end{array}$ \\
\hline 10. & $\begin{array}{l}\text { Memilih sub- } \\
\text { menu daerah }\end{array}$ & $\begin{array}{l}\text { Menampilkan form } \\
\text { sub-menu daerah }\end{array}$ & $\begin{array}{l}\text { Menampilkan form } \\
\text { sub-menu daerah }\end{array}$ \\
\hline 11. & $\begin{array}{l}\text { Menambah } \\
\text { daerah }\end{array}$ & $\begin{array}{l}\text { Aplikasi menambah } \\
\text { data baru dan } \\
\text { menyimpan data } \\
\text { yang baru database }\end{array}$ & $\begin{array}{l}\text { Aplikasi menambah } \\
\text { data baru dan } \\
\text { menyimpan data } \\
\text { yang baru database }\end{array}$ \\
\hline 13. & $\begin{array}{l}\text { Memilih sub- } \\
\text { menu dinas }\end{array}$ & $\begin{array}{l}\text { Menampilkan form } \\
\text { sub-menu dinas }\end{array}$ & $\begin{array}{l}\text { Menampilkan form } \\
\text { sub-menu dinas }\end{array}$ \\
\hline
\end{tabular}

\begin{tabular}{|c|c|c|c|}
\hline 14. & $\begin{array}{l}\text { Menambah } \\
\text { dinas }\end{array}$ & $\begin{array}{l}\text { Aplikasi menambah } \\
\text { data baru dan } \\
\text { menyimpan data } \\
\text { yang baru database }\end{array}$ & $\begin{array}{l}\text { Aplikasi menambah } \\
\text { data baru dan } \\
\text { menyimpan data } \\
\text { yang baru database }\end{array}$ \\
\hline 15. & $\begin{array}{l}\text { Mengubah } \\
\text { dinas }\end{array}$ & $\begin{array}{l}\text { Aplikasi mengubah } \\
\text { data lama dan } \\
\text { menyimpan data } \\
\text { yang baru pada } \\
\text { database }\end{array}$ & $\begin{array}{l}\text { Aplikasi mengubah } \\
\text { data lama dan } \\
\text { menyimpan data } \\
\text { yang baru pada } \\
\text { database }\end{array}$ \\
\hline 17. & $\begin{array}{l}\text { Memilih menu } \\
\text { dasar hukum }\end{array}$ & $\begin{array}{l}\text { Aplikasi } \\
\text { menampilkan form } \\
\text { dasar hukum }\end{array}$ & $\begin{array}{l}\text { Aplikasi } \\
\text { menampilkan form } \\
\text { dasar hukum }\end{array}$ \\
\hline 18. & $\begin{array}{l}\text { Menambah } \\
\text { data dasar } \\
\text { hukum }\end{array}$ & $\begin{array}{l}\text { Aplikasi menambah } \\
\text { data baru dan } \\
\text { menyimpan data } \\
\text { yang baru database }\end{array}$ & $\begin{array}{l}\text { Aplikasi menambah } \\
\text { data baru dan } \\
\text { menyimpan data } \\
\text { yang baru database }\end{array}$ \\
\hline 19. & $\begin{array}{l}\text { Menghapus } \\
\text { data dasar } \\
\text { hukum }\end{array}$ & $\begin{array}{l}\text { Aplikasi } \\
\text { menampilkan } \\
\text { konfirmasi sebelum } \\
\text { menghapus data } \\
\text { dan menghapus } \\
\text { data tersebut dari } \\
\text { database }\end{array}$ & $\begin{array}{l}\text { Aplikasi } \\
\text { menampilkan } \\
\text { konfirmasi sebelum } \\
\text { menghapus data } \\
\text { dan menghapus } \\
\text { data tersebut dari } \\
\text { database }\end{array}$ \\
\hline 20. & $\begin{array}{l}\text { Jenis file yang } \\
\text { dapat di- } \\
\text { upload }\end{array}$ & $\begin{array}{l}\text { Aplikasi hanya } \\
\text { dapat meng-upload } \\
\text { file seperti pdf, } \\
\text { doc/docx, dan jpg }\end{array}$ & $\begin{array}{l}\text { Aplikasi hanya } \\
\text { dapat meng-upload } \\
\text { file seperti pdf, } \\
\text { doc/docx, dan jpg }\end{array}$ \\
\hline 21. & $\begin{array}{l}\text { Batas ukuran } \\
\text { file yang dapat } \\
\text { di-upload }\end{array}$ & $\begin{array}{l}\text { Aplikasi hanya } \\
\text { menyimpan file } \\
\text { yang berukuran } \leq 2 \\
\text { Mb }\end{array}$ & $\begin{array}{l}\text { Aplikasi hanya } \\
\text { menyimpan file } \\
\text { yang berukuran } \leq 2 \\
\text { Mb }\end{array}$ \\
\hline \multicolumn{4}{|l|}{ Staf } \\
\hline 1. & $\begin{array}{l}\text { Mengisi data } \\
\text { pada laporan }\end{array}$ & $\begin{array}{l}\text { Aplikasi } \\
\text { menyimpan data } \\
\text { yang dimasukkan } \\
\text { ke dalam database }\end{array}$ & $\begin{array}{l}\text { Aplikasi } \\
\text { menyimpan data } \\
\text { yang dimasukkan } \\
\text { ke dalam database }\end{array}$ \\
\hline 2. & $\begin{array}{l}\text { Mengubah } \\
\text { data laporan } \\
\text { yang sedang } \\
\text { dibuat }\end{array}$ & $\begin{array}{l}\text { Aplikasi } \\
\text { menyimpan data } \\
\text { laporan yang baru } \\
\text { diubah }\end{array}$ & $\begin{array}{l}\text { Aplikasi } \\
\text { menyimpan data } \\
\text { laporan yang baru } \\
\text { diubah }\end{array}$ \\
\hline 3. & $\begin{array}{l}\text { Menghapus } \\
\text { data laporan } \\
\text { yang sedang } \\
\text { dibuat }\end{array}$ & $\begin{array}{l}\text { Aplikasi } \\
\text { menghapus data } \\
\text { laporan dari } \\
\text { database }\end{array}$ & $\begin{array}{l}\text { Aplikasi } \\
\text { menghapus data } \\
\text { laporan dari } \\
\text { database }\end{array}$ \\
\hline
\end{tabular}

Berdasarkan pengujian yang telah dilakukan terhadap aplikasi yang dibangun maka dapat disimpulkan bahwa:

1. Aplikasi dapat berjalan dengan baik

2. Kebutuhan pengguna terpenuhi

3. Fungsi-fungsi yang pada aplikasi berjalan sesuai dengan yang diharapkan

4. Tampilan aplikasi mudah dimengerti

\section{E. KESIMPULAN}

Berdasarkan hasil penelitian, maka dapat disimpulkan bahwa dengan adanya aplikasi ini: 
1. Admin dapat menerima laporan yang dikirim oleh staf BAPPEDA Kabupaten/Kota.

2. Staf BAPPEDA Kabupaten/Kota dapat membuat dan mengirim laporan DAK kepada admin.

3. Aplikasi ini dapat digunakan dengan baik oleh Sub Bidang Monitoring dan Pelaporan serta Staf BAPPEDA Kabupaten/Kota

Adapun saran untuk pengembangan aplikasi ini ke depannya yakni:

1. Aplikasi ini perlu dilakukan pengembangan dari sisi keamanan untuk menghindari $S Q L$ Injection.

2. Dapat menambahkan fitur untuk rincian pembagian alokasi dana untuk setiap SKPD.

3. Menambah fitur verifikasi untuk laporan yang masuk, apakah laporan diterima atau belum. Jika belum dikembalikan lagi ke SKPD bersangkutan.

\section{F. DAFTAR PUSTAKA}

Hidayatullah, P., Kawistara, J.K. 2015. Pemrograman Web. Bandung: Informatika.

DAK. 2015. Keputusan Menteri Keuangan No. 556/KMK.03/2000. [Online] Available http://kamuskeuangandaerah.com/inde x.php/Dana_Alokasi_Khusus_(DAK) [Accessed 30 September 2015].

Nugroho, B. 2008. Latihan Membuat Aplikasi Web PHP dan MySQL dengan Dreamweaver MX (6, 7, 2004 dan 8). Jogjakarta: Gava Media.

Puspitosari, H.A. 2011. Pemrograman Web Database dengan PHP \& MySQL. Yogyakarta: Skripta Media Creative.
Raharjo, B. 2011. Belajar Otodidak Membuat Database Menggunakan MySQL. Bandung: Informatika.

Raharjo, B., Heryanto, I., Rosdiana, K.E. 2014. Modul Pemrograman Web (HTML, PHP, \& MySQL). Bandung: Modula.

Rosa, A.S., Shalahuddin, M. 2015. Rekayasa Perangkat Lunak Terstruktur dan Berorientasi Objek. Bandung: Modula. 